\title{
Bacillus trypoxylicola sp. nov., xylanase-producing alkaliphilic bacteria isolated from the guts of Japanese horned beetle larvae (Trypoxylus dichotomus septentrionalis)
}

Correspondence Michio Sunairi sunairi@brs.nihon-u.ac.jp

\author{
Tomoko Aizawa, ${ }^{1} \dagger$ Makoto Urai, ${ }^{1} \dagger \ddagger$ Noriyuki Iwabuchi, ${ }^{1}$ \\ Mutsuyasu Nakajima ${ }^{1,2}$ and Michio Sunairi ${ }^{1}$ \\ ${ }^{1}$ Department of Applied Biological Sciences, College of Bioresource Sciences, Nihon University, \\ 1866 Kameino, Fujisawa, Kanagawa 252-8510, Japan \\ ${ }^{2}$ Environmental Program, Nihon University Advanced Research Institute for the Sciences and \\ Humanities, 12-5 Goban-cho Chiyoda, Tokyo 102-8251, Japan
}

Since the first report on alkali-active enzymes produced by alkaliphilic strains of the genus Bacillus, these bacteria have been studied extensively from an industrial point of view (Horikoshi, 1991, 1996; Nielsen et al., 1995; Yumoto et al., 1998) and there have been many reports of alkaliphilic or alkalitolerant species of Bacillus, including Bacillus agaradhaerens, B. alcalophilus, B. clarkii, B. clausii, B. gibsonii, B. halmapalus, B. halodurans, B. horikoshii, B. pseudalcaliphilus and B. pseudofirmus (Nielsen et al., 1995), B. okuhidensis (Li et al., 2002), B. krulwichiae (Yumoto et al., 2003), B. patagoniensis (Olivera et al., 2005), B. oshimensis (Yumoto

†These authors contributed equally to this work.

‡Present address: RIKEN (The Institute of Physical and Chemical Research), 2-1 Hirosawa, Wako, Saitama 351-0198, Japan.

The GenBank/EMBL/DDBJ accession numbers for the 16S rRNA gene sequences of strains SU1 ${ }^{\top}, 36 \mathrm{AC} 4$ and 36AC6 are AB434284, AB482197 and AB482198, respectively.

A photograph of a Japanese horned beetle larva, graphs showing the effects of sodium and potassium on growth of $B$. trypoxylicola strains and related strains and fatty acid compositions of $B$. trypoxylicola strains and related strains are available as supplementary material with the online version of this paper. et al., 2005), B. bogoriensis (Vargas et al., 2005), B. akibai, B. cellulosilyticus, B. hemicellulosilyticus, B. mannanilyticus and B. wakoensis (Nogi et al., 2005), B. okhensis (Nowlan et al., 2006), B. lehensis (Ghosh et al., 2007), B. qingdaonensis (Wang et al., 2007), B. murimartini and B. plakortidis (Borchert et al., 2007), B. polygoni (Aino et al., 2008), B. alkalinitrilicus (Sorokin et al., 2008a, 2009), B. alkalidiazotrophicus (Sorokin et al., 2008b), B. alkalitelluris (Lee et al., 2008) and B. aurantiacus (Borsodi et al., 2008). Larvae of the Japanese horned beetle, Trypoxylus (Allomyrina) dichotomus (Kono, 1931; Kurosawa, 1985), feed on decayed wood or leaf litter, but not fresh wood, and are assumed to play an important role in the degradation of polysaccharides produced by broadleaf trees in forests (Supplementary Fig. S1, available in IJSEM Online). It has been reported that the contents of the larval midgut have an alkaline $\mathrm{pH}$ (pH 10) and strong $\beta$-1,4-xylan-degrading activity (Wada et al., 2004). During screening for xylanolytic alkaliphiles from the guts of larvae of $T$. dichotomus subsp. septentrionalis (Takeishi et al., 2006), three strains, designated $\mathrm{SU}^{\mathrm{T}}$, 36AC4 and 36AC6, were isolated. Based on the results of phenotypic, genotypic, chemotaxonomic and 
phylogenetic analyses made in the present study, these strains were affiliated with the genus Bacillus; data obtained also suggest that the isolates represent a novel species of the genus Bacillus.

After having been enriched three times by being cultured in XA liquid medium [containing $\left(1^{-1}\right)$ : $5 \mathrm{~g}$ xylan (Sigma), $200 \mathrm{mg}$ polypeptone, $200 \mathrm{mg}$ Bacto yeast extract, $200 \mathrm{mg}$ $\mathrm{MgSO}_{4} \cdot 7 \mathrm{H}_{2} \mathrm{O}, 1 \mathrm{~g} \mathrm{~K}_{2} \mathrm{HPO}_{4}$ and $10 \mathrm{~g} \mathrm{~K}_{2} \mathrm{CO}_{3}(\mathrm{pH} 10)$ (Takeishi et al., 2006)], strain $\mathrm{SU}^{\mathrm{T}}$ was isolated from the gut of a larva on XA agar plates (solidified with $15 \mathrm{~g}$ agar $\mathrm{I}^{-1}$ ) at $30{ }^{\circ} \mathrm{C}$ under aerobic conditions. Strains 36AC4 and 36AC6 were both isolated from the midgut of a different larva at $30{ }^{\circ} \mathrm{C}$ under aerobic conditions by using a medium of the same composition as XA agar except that xylan was replaced by $0.5 \%$ glucose. The three strains formed yellowish, flat, round colonies with entire margins on XA agar plates. On these plates, the strains formed a clear zone around each colony, indicating the presence of xylanase activity. The strains showed good growth in alkaline tryptic soy medium [ATSM, containing $\left(1^{-1}\right) 30 \mathrm{~g}$ Bacto tryptic soy broth (Difco) and $\left.10 \mathrm{~g} \mathrm{~K}_{2} \mathrm{CO}_{3}(\mathrm{pH} 9)\right]$ at $17-37{ }^{\circ} \mathrm{C}$, with optimum growth at $30{ }^{\circ} \mathrm{C}$, but did not grow at $40{ }^{\circ} \mathrm{C}$. The effect of $\mathrm{pH}$ on growth was determined as described previously (Nielsen et al., 1995). Strains SU1 ${ }^{\mathrm{T}}, 36 \mathrm{AC} 4$ and 36AC6 showed good growth at $\mathrm{pH} \mathrm{8-10,} \mathrm{with} \mathrm{optimum}$ growth at $\mathrm{pH} 9$, but little or no growth below $\mathrm{pH} 7$ or above $\mathrm{pH} 11$ when cultured at $30{ }^{\circ} \mathrm{C}$ for 5 days. The strains showed good growth on ATS agar (ATSM solidified by the addition of $15 \mathrm{~g}_{\text {agar }} \mathrm{l}^{-1}$; $\mathrm{pH}$ 9) under aerobic conditions, but not under a nitrogen atmosphere of $99.99 \%$, suggesting that they are aerobic. The presence of spores was determined by the Schaeffer-Fulton staining method (Smibert \& Krieg, 1994) as well as by phase-contrast microscopy. Spores were terminal in position and ellipsoidal; slight swelling of the sporangia was observed. Cells of strains SU1 ${ }^{\mathrm{T}}, 36 \mathrm{AC} 4$ and 36AC6 stained Gram-positive (Ryu, 1938) and showed no motility. Morphology was observed by phase-contrast microscopy. Cells cultured on
$\mathrm{XA}$ agar plates at $30{ }^{\circ} \mathrm{C}$ for 2 days were irregular rods, $0.6 \mu \mathrm{m}$ wide and $0.8-2.0 \mu \mathrm{m}$ long.

The 16S rRNA genes of the strains were amplified by PCR using universal primers (Tamura \& Hatano, 2001) and nearly complete $16 \mathrm{~S}$ rRNA gene sequences (1509 bp) were determined. Sequence match analysis using the Ribosome Database Project II revealed that the $16 \mathrm{~S}$ rRNA gene sequences of strains SU1 ${ }^{\mathrm{T}}, 36 \mathrm{AC} 4$ and 36AC6 showed higher similarities to sequences of the type strains of alkaliphilic Bacillus species than to those of other Bacillus species. 16S rRNA gene sequence similarities of strain SU1 ${ }^{\mathrm{T}}$ to strain 36AC4, strain 36AC6, B. pseudalcaliphilus CIP $105304^{\mathrm{T}}$ and B. alcalophilus NBRC $15653^{\mathrm{T}}$ were 99.3, 99.5, 97.4 and $97.0 \%$, respectively. Phylogenetic relationships with closely related species were determined by using MEGA version 4 (Tamura et al., 2007) and the PHYLIP 3.65 package (Felsenstein, 2005) after multiple alignments of the data performed with CLUSTAL_X (Thompson et al., 1997). Evolutionary distances were computed as described previously (Jukes \& Cantor, 1969). Phylogenetic trees were constructed by using the maximum-parsimony (Kluge \& Farris, 1969), maximum-likelihood (Felsenstein, 1981) and neighbour-joining (Saitou \& Nei, 1987) methods. The reliabilities of these tree topologies were evaluated by bootstrap analysis with 1000 replicates (Felsenstein, 1985). Phylogenetic trees constructed by these three methods were similar topologically and showed that strains SU1 ${ }^{\mathrm{T}}, 36 \mathrm{AC} 4$ and 36AC6 belonged to the genus Bacillus. The phylogenetic tree constructed using the neighbour-joining method is shown in Fig. 1. Although the strains showed high degrees of $16 \mathrm{~S}$ rRNA gene sequence similarity to described species of the genus, they formed a separate line of descent in the phylogenetic cluster of the genus. Stackebrandt \& Goebel (1994) have pointed out that a high degree of 16S rRNA gene sequence similarity $(\geqslant 97 \%)$ is of limited value for differentiating species and that DNA-DNA hybridization studies need to be performed to determine species affiliation under these circumstances. Therefore, DNA-

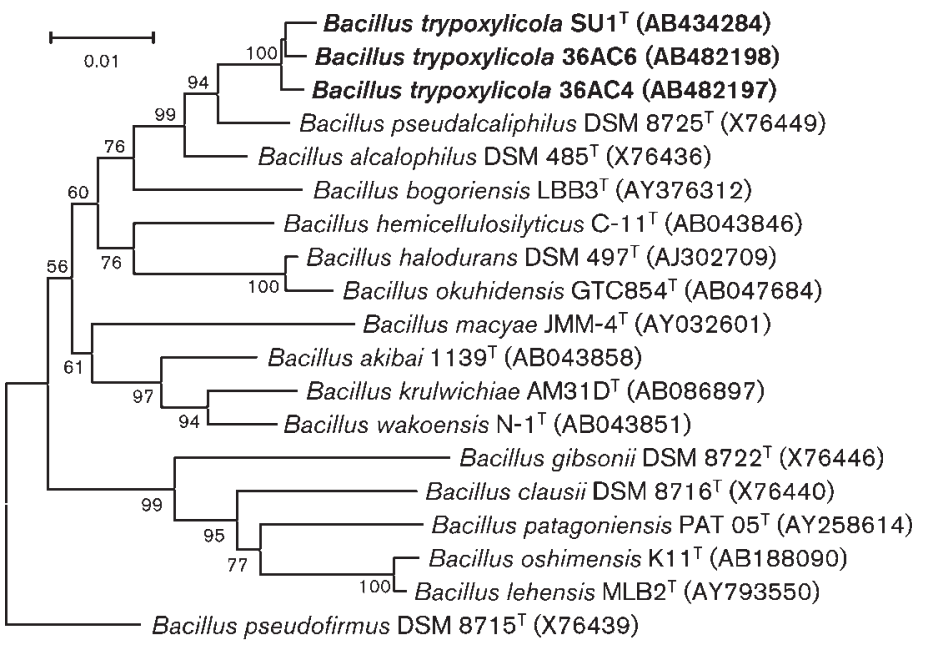

Fig. 1. Neighbour-joining tree based on nearly complete 16S rRNA gene sequences (positions 58-1440 of the Escherichia coli $16 \mathrm{~S}$ rRNA gene) showing the position of strains $\mathrm{SU}_{1}{ }^{\top}, 36 \mathrm{AC} 4$ and 36AC6 among their phylogenetic neighbours. Numbers at branch nodes are percentages based on 1000 resamplings; only values over $50 \%$ are given. The sequence of Bacillus pseudofirmus DSM $8715^{\top}$ was used as an outgroup. Bar, 0.01 substitutions per nucleotide position. 
DNA hybridization studies of the novel strains and closely related strains from the phylogenetic tree were performed by using the microplate hybridization method (Ezaki et al., 1988, 1989; Tamura et al., 1999). The DNA-DNA relatedness values of strain $\mathrm{SU}^{\mathrm{T}}$ with strains $36 \mathrm{AC} 4$ and 36AC6 were 80.9 and $85.8 \%$, respectively, which were higher than the recommended threshold value for the delineation of genomic species (70\%; Wayne et al., 1987). Strain $\mathrm{SU} 1^{\mathrm{T}}$ exhibited relatively low levels of DNA-DNA relatedness to B. pseudalcaliphilus CIP $105304^{\mathrm{T}}$ (26.4\%) and B. alcalophilus NBRC $15653^{\mathrm{T}}$ (19.6\%), indicating that it was not related to them at the species level. These data suggest that strains SU1 ${ }^{\mathrm{T}}, 36 \mathrm{AC} 4$ and 36AC6 represent a novel species of the genus Bacillus.

The major isoprenoid quinone of the strains was MK-7, determined using a Quattro premier mass spectrometer coupled to an ACUITY UPLC (UPLC/MS/MS; Waters). The DNA G $+\mathrm{C}$ content was determined as described previously (Tamaoka \& Komagata, 1984). The DNA G + C contents of SU1 ${ }^{\mathrm{T}}, 36 \mathrm{AC} 4,36 \mathrm{AC} 6, \mathrm{~B}$. pseudalcaliphilus CIP $105304^{\mathrm{T}}$ and B. alcalophilus NBRC $15653^{\mathrm{T}}$ were $37.4,37.5$, $37.7,39.0$ and $37.4 \mathrm{~mol} \%$, respectively. The isolates and the type strains of closely related species were cultivated on ATS agar ( $\mathrm{pH}$ 9.0) for 3 days at $30{ }^{\circ} \mathrm{C}$; cellular fatty acids were then saponified, methylated and extracted as described previously (Tamura et al., 1994). Fatty acid methyl esters were analysed by using a Shimadzu QP5050 GC-MS equipped with an SPB-1 column (Supelco). The fatty acid compositions of strains SU1 ${ }^{\mathrm{T}}, 36 \mathrm{AC} 4$ and 36AC6 were similar, containing iso- $\mathrm{C}_{15: 0}$, anteiso- $\mathrm{C}_{15: 0}$, anteiso$\mathrm{C}_{17: 0}$ and iso- $\mathrm{C}_{17: 0}$ as the major fatty acids (Supplementary Table S1). Fatty acid compositions were similar to those of B. pseudalcaliphilus CIP $105304^{\mathrm{T}}$ and $B$. alcalophilus NBRC $15653^{\mathrm{T}}$ except for the relative amounts of iso- $\mathrm{C}_{16: 0}$ and iso- $\mathrm{C}_{17: 1}$. The isomer type of diamino acid of the cell-wall peptidoglycan was determined as described previously (Komagata \& Suzuki, 1987). Strains $\mathrm{SU}^{\mathrm{T}}, 36 \mathrm{AC} 4$ and 36AC6 contained meso-diaminopimelic acid as the diagnostic diamino acid. Standard physiological tests were carried out as described previously (Smibert \& Krieg, 1994). Enzyme activity was assessed by using the API 20E, API 20NE and API ZYM systems (bioMérieux) according to the manufacturer's instructions (incubation times of up to $7 \mathrm{~h}$ ). The phenylalanine deamination test was performed as described by Gordon et al. (1973). Acid production from carbohydrates and utilization of various substrates as sole carbon sources were tested by using the API $50 \mathrm{CH}$ system with the medium described by Hugh \& Leifson (1953) with a modification for alkaliphiles (Yumoto et al., 2003). Resistance to antibiotics was examined by using the API VET system (bioMérieux) as described by the manufacturer. Strains $\mathrm{SU}^{\mathrm{T}}, 36 \mathrm{AC} 4$ and 36AC6 could be distinguished from the two related alkaliphilic Bacillus species, B. pseudalcaliphilus and B. alcalophilus, on the basis of physiological characteristics (Table 1). In addition, growth of the isolates in the presence of sodium or potassium salts differed from that observed with B. pseudalcaliphilus CIP $105304^{\mathrm{T}}$ and $B$. alcalophilus $\mathrm{NBRC} 15653^{\mathrm{T}}$. Strains $\mathrm{SU1} 1^{\mathrm{T}}, 36 \mathrm{AC} 4$ and 36AC6 showed good growth $\left(\mathrm{OD}_{660}=1.2-1.3\right)$ in tryptic soy medium (Difco) adjusted to $\mathrm{pH} 9$ with $\mathrm{KOH}$ compared with growth observed in the medium adjusted to $\mathrm{pH} 9$ with $\mathrm{NaOH} \quad\left(\mathrm{OD}_{660}=0.5-0.6\right)$, whereas $B$. pseudalcaliphilus CIP $105304^{\mathrm{T}}$ and B. alcalophilus NBRC $15653^{\mathrm{T}}$ showed good growth on medium adjusted with either hydroxide $\left(\mathrm{OD}_{660}=1.2-1.5\right)$. The effects of $\mathrm{NaCl}$ or $\mathrm{KCl}$ on the growth of SU1 ${ }^{\mathrm{T}}, 36 \mathrm{AC} 4,36 \mathrm{AC} 6, \mathrm{~B}$. pseudalcaliphilus CIP $105304^{\mathrm{T}}$ and B. alcalophilus NBRC $15653^{\mathrm{T}}$ were determined on ATSM containing various concentrations of $\mathrm{NaCl}$ or $\mathrm{KCl}$ (Supplementary Fig. S2). Strains $\mathrm{SU}_{1}^{\mathrm{T}}, 36 \mathrm{AC} 4$, and 36AC6 showed a preference for $\mathrm{K}^{+}$over $\mathrm{Na}^{+}$in the alkaline medium, i.e. they showed good growth up to $12 \%(\mathrm{w} / \mathrm{v}) \mathrm{KCl}$, but little or no growth in the presence of $7 \%(\mathrm{w} / \mathrm{v}) \mathrm{NaCl}$ or above (Supplementary Fig. S2a-c). Growth of B. pseudalcaliphilus CIP $105304^{\mathrm{T}}$ and B. alcalophilus $\mathrm{NBRC} 15653^{\mathrm{T}}$ in the presence of $\mathrm{KCl}$ or $\mathrm{NaCl}$ did not show such big differences (Supplementary Fig. S2d, e), and the former showed higher tolerance to both salts than the latter. A similar preference for $\mathrm{K}^{+}$over $\mathrm{Na}^{+}$in alkaline medium has been reported for alkaliphiles isolated from soil (Kitada \& Horikoshi, 1987) and the alkaline gut of soil-feeding termites (Ohkuma et al., 2003; Thongaram et al., 2003) and T. dichotomus (Takeishi et al., 2006).

Therefore, based on the phenotypic and phylogenetic characterization described above, strains SU1 ${ }^{\mathrm{T}}, 36 \mathrm{AC} 4$, and 36AC6 represent a novel species, for which the name Bacillus trypoxylicola sp. nov. is proposed.

\section{Description of Bacillus trypoxylicola sp. nov.}

Bacillus trypoxylicola [try.po.xy.li'co.la. N.L. masc. n. Trypoxylus systematic genus name of the Japanese horned beetle (Coleoptera: Scarabaeidae), the source of the type strain; L. suff. - cola an inhabitant of a place, a resident; N.L. masc. n. trypoxylicola the Japanese horned beetle dweller].

Gram-stain-positive, aerobic, non-motile and rod-shaped ( $0.6 \mu \mathrm{m}$ wide and 0.8 to $2.0 \mu \mathrm{m}$ long). Spores are terminal in position and ellipsoidal; slightly swollen sporangia are observed. Colonies are yellowish, flat and round with entire margins after 3 days cultivation at $30{ }^{\circ} \mathrm{C}$ on ATS agar (pH 9.0). Growth occurs between 17 and $37^{\circ} \mathrm{C}$; optimum growth at $30^{\circ} \mathrm{C}$. The $\mathrm{pH}$ range for growth is $8-10$, with optimum growth at $\mathrm{pH} 9$. Growth occurs at higher concentrations of $\mathrm{KCl}(0-17 \%$, w/v) than of $\mathrm{NaCl}(0-$ $5 \%, w / v)$. Positive for hydrolysis of xylan, but negative for hydrolysis of gelatin, casein and Tweens 20, 40, 60 and 80. Positive for oxidase, acid and alkaline phosphatases, catalase, esterase (C4), esterase lipase (C8), $\alpha$-galactosidase, $\beta$-galactosidase, $\alpha$-glucosidase, $\beta$-glucosidase, $\beta$-glucuronidase, naphthol-AS-BI-phosphohydrolase and leucine, trypsin and valine arylamidases, but negative for $N$-acetyl- $\beta$ glucosaminidase, $\alpha$-chymotrypsin, cystine arylamidase, $\alpha$ fucosidase, $\alpha$-mannosidase, lipase (C4), lysine and ornithine decarboxylases, tryptophan deaminase, urease, 
Table 1. Physiological characteristics of strains of Bacillus trypoxylicola sp. nov. and closely related Bacillus type strains

Strains: 1, B. trypoxylicola sp. nov. SU1 ${ }^{\mathrm{T}}, 36 \mathrm{AC} 4$ and 36AC6; 2, B. pseudalcaliphilus CIP $105304^{\mathrm{T}}$; 3, B. alcalophilus NBRC $15653^{\mathrm{T}}$. Data were obtained in this study. All strains had the following characteristics: positive for Gram staining, oxidase and catalase; positive for alkaline phosphatase, esterase lipase (C8), naphthol-ASBI-phosphohydrolase and $\alpha$-glucosidase (API ZYM); negative for hydrolysis of Tween 80 and deamination of phenylalanine; negative for lipase (C4), $N$-acetyl-D-glucosaminidase, $\alpha$-mannosidase, $\alpha$ fucosidase, cystine arylamidase, Voges-Proskauer test, lysine and ornithine decarboxylases, tryptophan deaminase, indole production, hydrogen sulfide production, urease, proteinase, arginine dihydrolase and reduction of nitrate and nitrite (API ZYM, API 20E and API 20NE); positive for acid production from D-glucose, D-fructose, maltose, sucrose, trehalose, starch and glycogen (API 50CH); negative for acid production from erythritol, D-arabinose, L-xylose, D-adonitol, L-sorbose, dulcitol, inositol, arbutin, melezitose, D-lyxose, D-fucose, D- and L-arabitol, potassium gluconate and potassium 5-ketogluconate (API 50CH); positive for utilization of glycerol, methyl $\beta$-Dxylopyranoside, D-galactose, D-glucose, D-fructose, L-rhamnose, Dmannitol, methyl $\alpha$-D-glucopyranoside, arbutin, salicin, cellobiose, lactose, sucrose, trehalose, starch and glycogen (API 50CH); negative for utilization of erythritol, L-xylose, D-adonitol, L-sorbose, dulcitol, D-sorbitol, inulin, melezitose, xylitol, D- and L-arabitol, potassium gluconate and potassium 5-ketogluconate (API 50CH); resistant to metronidazole and nitrofurantoin (API VET); and sensitive to amoxicillin, augmentin, cephalothin, chloramphenicol, doxycycline, gentamicin, penicillin, oxacillin and tetracycline (API VET). +, Positive; -, negative; (+), weakly positive.

\begin{tabular}{|lccc|}
\hline Characteristic & $\mathbf{1}$ & $\mathbf{2}$ & $\mathbf{3}$ \\
\hline Growth in: & & & \\
$7 \%(\mathrm{w} / \mathrm{v}) \mathrm{NaCl}$ & - & + & + \\
$10 \%(\mathrm{w} / \mathrm{v}) \mathrm{NaCl}$ & - & + & - \\
$12 \%(\mathrm{w} / \mathrm{v}) \mathrm{KCl}$ & + & + & - \\
Hydrolysis of: & & & \\
Tween 20 & - & - & $(+)$ \\
Tweens 40 and 60 & - & + & + \\
Casein & - & + & + \\
Gelatin & - & + & + \\
Activity of (API ZYM): & & & \\
Esterase (C4) & + & + & - \\
Leucine arylamidase & + & - & + \\
Valine arylamidase & + & - & - \\
Trypsin & + & - & - \\
$\alpha$-Chymotrypsin & - & + & + \\
Acid phosphatase & + & + & - \\
$\alpha$-Galactosidase & + & - & - \\
$\beta$-Galactosidase & + & - & + \\
$\beta$-Glucuronidase & + & - & - \\
$\beta$-Glucosidase & + & - & - \\
Acid production from $($ API $50 \mathrm{CH}):$ & & & \\
L-Arabinose & + & - & + \\
D-Ribose & + & - & + \\
D-Xylose & + & - & + \\
D-Galactose & - & - \\
D-Mannose & + & + \\
\hline
\end{tabular}

Table 1. cont.

\begin{tabular}{|c|c|c|c|}
\hline Characteristic & 1 & 2 & 3 \\
\hline L-Rhamnose & + & + & - \\
\hline D-Mannitol & + & - & - \\
\hline D-Sorbitol & $(+)$ & - & + \\
\hline Methyl $\alpha$-D-mannopyranoside & - & - & + \\
\hline Methyl $\alpha$-D-glucopyranoside & - & + & + \\
\hline$N$-Acetylglucosamine & - & - & + \\
\hline Cellobiose & + & - & - \\
\hline Lactose & + & - & + \\
\hline Melibiose & + & - & + \\
\hline Inulin & - & - & + \\
\hline Raffinose & + & - & + \\
\hline D-Tagatose & - & - & + \\
\hline Potassium 5-ketogluconate & - & - & $(+)$ \\
\hline \multicolumn{4}{|l|}{ Utilization of (API 50CH): } \\
\hline D-Arabinose & - & - & $(+)$ \\
\hline D-Ribose & - & + & + \\
\hline D-Mannose & + & - & + \\
\hline Inositol & - & - & $(+)$ \\
\hline Methyl $\alpha$-D-mannopyranoside & + & - & - \\
\hline $\mathrm{N}$-Acetylglucosamine & - & - & + \\
\hline Melibiose & + & - & + \\
\hline Raffinose & + & - & + \\
\hline Turanose & - & + & + \\
\hline D-Lyxose & - & + & + \\
\hline D-Tagatose & - & + & + \\
\hline Potassium 2-ketogluconate & + & - & - \\
\hline \multicolumn{4}{|l|}{ Resistance to (API VET): } \\
\hline Streptomycin & - & + & - \\
\hline Kanamycin & + & $(+)$ & - \\
\hline Erythromycin & - & + & + \\
\hline Lincomycin & - & + & - \\
\hline Colistin & - & + & + \\
\hline Sulfamethizole & + & - & + \\
\hline Flumequine & + & - & $(+)$ \\
\hline Oxolinic acid & + & - & $(+)$ \\
\hline Rifampicin & - & + & - \\
\hline
\end{tabular}

arginine dihydrolase and proteinase (API ZYM, API 20E and API 20NE systems). Negative for the Voges-Proskauer test, indole production, hydrogen sulfide production and reduction of nitrate and nitrite (API 20E and API 20NE systems). Negative for the phenylalanine deamination test. Positive for acid production from L-arabinose, D-ribose, Dxylose, D-galactose, D-glucose, D-fructose, D-mannose, Lrhamnose, D-mannitol, D-sorbitol, cellobiose, maltose, lactose, melibiose, sucrose, trehalose, raffinose, starch and glycogen, but negative for acid production from erythritol, D-arabinose, L-xylose, D-adonitol, L-sorbose, dulcitol, inositol, methyl $\alpha$-D-glucopyranoside, methyl $\alpha$-D-mannopyranoside, $\mathrm{N}$-acetylglucosamine, arbutin, inulin, melezitose, D-lyxose, D-fucose, D- and L-arabitol, potassium gluconate, potassium 2-ketogluconate and potassium 5ketogluconate (API 50CH system). Positive for utilization of glycerol, methyl $\beta$-D-xylopyranoside, D-galactose, Dglucose, D-fructose, D-mannose, L-rhamnose, D-mannitol, 
methyl $\alpha$-D-glucopyranoside, methyl $\alpha$-D-mannopyranoside, arbutin, salicin, cellobiose, lactose, melibiose, sucrose, trehalose, raffinose, starch, glycogen and potassium 2ketogluconate, but negative for utilization of erythritol, Darabinose, D-ribose, L-xylose, D-adonitol, L-sorbose, dulcitol, inositol, D-sorbitol, $N$-acetylglucosamine, inulin, melezitose, xylitol, turanose, D-lyxose, D-tagatose, D- and Larabitol, potassium gluconate and potassium 5-ketogluconate (API 50CH system). Resistant to flumequine, kanamycin, metronidazole, nitrofurantoin, oxolinic acid and sulfamethizole, but sensitive to amoxicillin, apramycin, augmentin, cefoperazone, cephalothin, chloramphenicol, colistin, doxycycline, erythromycin, gentamicin, lincomycin, oxacillin, penicillin, pristinamycin, rifampicin, streptomycin, spectinomycin, tetracycline and tylosin (API VET system). The major isoprenoid quinone is MK-7, the cellwall peptidoglycan contains meso-diaminopimelic acid, and the major fatty acids ( $>10 \%$ of total fatty acids) are iso- $\mathrm{C}_{15: 0}$, anteiso- $\mathrm{C}_{15: 0}$, anteiso- $\mathrm{C}_{17: 0}$ and iso- $\mathrm{C}_{17: 0}$.

The type strain is $\mathrm{SU}^{\mathrm{T}}$ (=NBRC $102646^{\mathrm{T}}=\mathrm{KCTC}$ $13244^{\mathrm{T}}$ ), isolated from the gut of a Japanese horned beetle larva (Trypoxylus dichotomus septentrionalis). The DNA $\mathrm{G}+\mathrm{C}$ content of the type strain is $37.4 \mathrm{~mol} \%$.

\section{Acknowledgements}

We are most grateful to T. Beppu and S. Sasaki for giving us the opportunity to conduct this research and give thanks to K. Ueda at the Life Science Center for use of instrumental facilities. We acknowledge H. Anzai, H. Matsufuji, Y. Shimizu, K. Shimoda, M. Suzuki and various members of our laboratories for their technical assistance and encouragement. We acknowledge M. Miyashita and Y. Nakagawa at the NBRC for deposition of the isolates and M. Hyoudou, M. Kogure, N. Murayama and N. Sekino at the Integrated Research Institute for their technical assistance. This study was partly supported by a grant-in-aid for scientific research from the Japan Society for the Promotion of Science, the 'Center of Excellence in 21st Century Projects' and the 'High-tech Research Center Program' of the Ministry of Education, Culture, Sports, Science, and Technology of Japan.

\section{References}

Aino, K., Hirota, K., Matsuno, T., Morita, N., Nodasaka, Y., Fujiwara, T., Matsuyama, H., Yoshimune, K. \& Yumoto, I. (2008). Bacillus polygoni sp. nov., a moderately halophilic, non-motile obligate alkaliphile isolated from indigo balls. Int J Syst Evol Microbiol 58, 120-124.

Borchert, M. S., Nielsen, P., Graeber, I., Kaesler, I., Szewzyk, U., Pape, T., Antranikian, G. \& Schäfer, T. (2007). Bacillus plakortidis sp. nov. and Bacillus murimartini sp. nov., novel alkalitolerant members of rRNA group 6. Int J Syst Evol Microbiol 57, 2888-2893.

Borsodi, A. K., Márialigeti, K., Szabó, G., Palatinszky, M., Pollák, B., Kéki, Z., Kovács, A. L., Schumann, P. \& Tóth, E. M. (2008). Bacillus aurantiacus sp. nov., an alkaliphilic and moderately halophilic bacterium isolated from Hungarian soda lakes. Int J Syst Evol Microbiol 58, 845-851.

Ezaki, T., Hashimoto, Y., Takeuchi, N., Yamamoto, H., Liu, S. L., Miura, H., Matsui, K. \& Yabuuchi, E. (1988). Simple genetic method to identify viridans group streptococci by colorimetric dot hybridization and fluorometric hybridization in microdilution wells. $J$ Clin Microbiol 26, 1708-1713.

Ezaki, T., Hashimoto, Y. \& Yabuuchi, E. (1989). Fluorometric deoxyribonucleic acid-deoxyribonucleic acid hybridization in microdilution wells as an alternative to membrane filter hybridization in which radioisotopes are used to determine genetic relatedness among bacterial strains. Int J Syst Bacteriol 39, 224-229.

Felsenstein, J. (1981). Evolutionary trees from DNA sequences: a maximum likelihood approach. J Mol Evol 17, 368-376.

Felsenstein, J. (1985). Confidence limits on phylogenies: an approach using the bootstrap. Evolution 39, 783-791.

Felsenstein, J. (2005). PHYLIP (phylogeny inference package) version 3.65. Distributed by the author. Department of Genome Sciences, University of Washington, Seattle, USA.

Ghosh, A., Bhardwaj, M., Satyanarayana, T., Khurana, M., Mayilraj, S. \& Jain, R. K. (2007). Bacillus lehensis sp. nov., an alkalitolerant bacterium isolated from soil. Int J Syst Evol Microbiol 57, 238-242.

Gordon, R. E., Haynes, W. C. \& Pang, C. H.-N. (1973). The Genus Bacillus. US Department of Agriculture Handbook no. 427. Washington, DC: Agricultural Research Service.

Horikoshi, K. (1991). Isolation and classification of alkalophilic microorganisms. In Microorganisms in Alkaline Environments, pp. 1524. Edited by K. Horikoshi. Tokyo: Kodansha.

Horikoshi, K. (1996). Alkaliphiles - from an industrial point of view. FEMS Microbiol Rev 18, 259-270.

Hugh, R. \& Leifson, E. (1953). The taxonomic significance of fermentative versus oxidative metabolism of carbohydrates by various Gram-negative bacteria. J Bacteriol 66, 24-26.

Jukes, T. H. \& Cantor, C. R. (1969). Evolution of protein molecules. In Mammalian Protein Metabolism, vol. 3, pp. 21-132. Edited by H. N. Munro. New York: Academic Press.

Kitada, M. \& Horikoshi, K. (1987). Bioenergetic properties of alkalophilic Bacillus sp. strain C-59 on an alkaline medium containing $\mathrm{K}_{2} \mathrm{CO}_{3}$. J Bacteriol 169, 5761-5765.

Kluge, A. G. \& Farris, J. S. (1969). Quantitative phyletics and the evolution of anurans. Syst Zool 18, 1-32.

Komagata, K. \& Suzuki, K. (1987). Lipid and cell-wall analysis in bacterial systematics. Methods Microbiol 19, 161-207.

Kono, H. (1931). Die Trypoxylus-Arten aus Japan und Formosa (Col. Scarabaeidae). Insecta Matsumurana 5, 159-160 (in German).

Kurosawa, Y. (1985). Siiphidae. In The Coleoptera of Japan in Color, vol. 2. Edited by S. Ueno, Y. Kurosawa \& M. Sato. Osaka: Hoikusha.

Lee, J.-C., Lee, G. S., Park, D.-J. \& Kim, C.-J. (2008). Bacillus alkalitelluris sp. nov., an alkaliphilic bacterium isolated from sandy soil. Int J Syst Evol Microbiol 58, 2629-2634.

Li, Z., Kawamura, Y., Shida, O., Yamagata, S., Deguchi, T. \& Ezaki, T. (2002). Bacillus okuhidensis sp. nov., isolated from the Okuhida spa area of Japan. Int J Syst Evol Microbiol 52, 1205-1209.

Nielsen, P., Fritze, D. \& Priest, F. G. (1995). Phenetic diversity of alkaliphilic Bacillus strains: proposal for nine new species. Microbiology 141, 1745-1761.

Nogi, Y., Takami, H. \& Horikoshi, K. (2005). Characterization of alkaliphilic Bacillus strains used in industry: proposal of five novel species. Int J Syst Evol Microbiol 55, 2309-2315.

Nowlan, B., Dodia, M. S., Singh, S. P. \& Patel, B. K. C. (2006). Bacillus okhensis sp. nov., a halotolerant and alkalitolerant bacterium from an Indian saltpan. Int J Syst Evol Microbiol 56, 1073-1077.

Ohkuma, M., Shimizu, H., Thongaram, T., Kosono, S., Moriya, K., Trakulnaleamsai, S., Noparatnaraporn, N. \& Kudo, T. (2003). An 
alkaliphilic and xylanolytic Paenibacillus species isolated from the gut of a soil-feeding termite. Microbes Environ 18, 145-151.

Olivera, N., Siñeriz, F. \& Breccia, J. D. (2005). Bacillus patagoniensis sp. nov., a novel alkalitolerant bacterium from the rhizosphere of Atriplex lampa in Patagonia, Argentina. Int J Syst Evol Microbiol 55, 443-447.

Ryu, E. (1938). On the Gram-differentiation of bacteria by the simplest method. J Jpn Soc Vet Sci 17, 31.

Saitou, N. \& Nei, M. (1987). The neighbor-joining method: a new method for reconstructing phylogenetic trees. Mol Biol Evol 4, 406425.

Smibert, R. M. \& Krieg, N. R. (1994). Phenotypic characterization. In Methods for General and Molecular Bacteriology, pp. 607-654. Edited by P. Gerhardt, R. G. E. Murray, W. A. Wood \& N. R. Krieg. Washington, DC: American Society for Microbiology.

Sorokin, D. Y., van Pelt, S. \& Tourova, T. P. (2008a). Utilization of aliphatic nitriles under haloalkaline conditions by Bacillus alkalinitrilicus sp. nov. isolated from soda solonchak soil. FEMS Microbiol Lett 288, 235-240.

Sorokin, I. D., Kravchenko, I. K., Tourova, T. P., Kolganova, T. V., Boulygina, E. S. \& Sorokin, D. Y. (2008b). Bacillus alkalidiazotrophicus sp. nov., a diazotrophic, low salt-tolerant alkaliphile isolated from Mongolian soda soil. Int J Syst Evol Microbiol 58, 2459-2464.

Sorokin, D. Y., van Pelt, S. \& Tourova, T. P. (2009). Bacillus alkalinitrilicus sp. nov. In List of New Names and New Combinations Previously Effectively, but not Validly, Published, Validation List no. 125. Int J Syst Evol Microbiol 59, 1-2.

Stackebrandt, E. \& Goebel, B. M. (1994). Taxonomic note: a place for DNA-DNA reassociation and 16S rRNA sequence analysis in the present species definition in bacteriology. Int J Syst Bacteriol 44, 846849.

Takeishi, H., Anzai, H., Urai, M., Aizawa, T., Wada, N., Iwabuchi, N., Sunairi, M. \& Nakajima, M. (2006). Xylanolytic and alkaliphilic Dietzia sp. isolated from larvae of the Japanese horned beetle, Trypoxylus dichotomus. Actinomycetologica 20, 49-54.

Tamaoka, J. \& Komagata, K. (1984). Determination of DNA base composition by reversed-phase high-performance liquid chromatography. FEMS Microbiol Lett 25, 125-128.

Tamura, T. \& Hatano, K. (2001). Phylogenetic analysis of the genus Actinoplanes and transfer of Actinoplanes minutisporangius Ruan et al. 1986 and 'Actinoplanes aurantiacus' to Cryptosporangium minutisporangium comb. nov. and Cryptosporangium aurantiacum sp. nov. Int $J$ Syst Evol Microbiol 51, 2119-2125.

Tamura, T., Nakagaito, Y., Nishii, T., Hasegawa, T., Stackebrandt, E. \& Yokota, A. (1994). A new genus of the order Actinomycetales,
Couchioplanes gen. nov., with descriptions of Couchioplanes caeruleus (Horan and Brodsky 1986) comb. nov. and Couchioplanes caeruleus subsp. azureus subsp. nov. Int J Syst Bacteriol 44, 193-203.

Tamura, T., Hayakawa, M. \& Hatano, K. (1999). Sporichthya brevicatena sp. nov. Int J Syst Bacteriol 49, 1779-1784.

Tamura, K., Dudley, J., Nei, M. \& Kumar, S. (2007). MEGA4: molecular evolutionary genetics analysis (MEGA) software version 4.0. Mol Biol Evol 24, 1596-1599.

Thompson, J. D., Gibson, T. J., Plewniak, F., Jeanmougin, F. \& Higgins, D. G. (1997). The CLUSTAL_X windows interface: flexible strategies for multiple sequence alignment aided by quality analysis tools. Nucleic Acids Res 25, 4876-4882.

Thongaram, T., Kosono, S., Ohkuma, M., Hongoh, Y., Kitada, M., Yoshinaka, T., Trakulnaleamsai, S., Noparatnaraporn, N. \& Kudo, T. (2003). Gut of higher termites as a niche for alkaliphiles as shown by culture-based and culture-independent studies. Microbes Environ 18, 152-159.

Vargas, V. A., Delgado, O. D., Hatti-Kaul, R. \& Mattiasson, B. (2005). Bacillus bogoriensis sp. nov., a novel alkaliphilic, halotolerant bacterium isolated from a Kenyan soda lake. Int J Syst Evol Microbiol 55, 899-902.

Wada, N., Takeishi, H., Urai, M., Iwabuchi, N., Sunairi, M., Nakajima, N. \& Anzai, H. (2004). Microbial flora in digestive tract of Tripoxylus dichotoma (L.) larvae. In 10th International Symposium on Microbial Ecology, Cancun, Mexico, abstract 266. Heteren: International Society for Microbial Ecology.

Wang, Q. F., Li, W., Liu, Y. L., Cao, H. H., Li, Z. \& Guo, G. Q. (2007). Bacillus qingdaonensis sp. nov., a moderately haloalkaliphilic bacterium isolated from a crude sea-salt sample collected near Qingdao in eastern China. Int J Syst Evol Microbiol 57, 1143-1147.

Wayne, L. G., Brenner, D. J., Colwell, R. R., Grimont, P. A. D., Kandler, O., Krichevsky, M. I., Moore, L. H., Moore, W. E. C., Murray, R. G. E. \& other authors (1987). International Committee on Systematic Bacteriology. Report of the ad hoc committee on reconciliation of approaches to bacterial systematics. Int J Syst Bacteriol 37, 463-464.

Yumoto, I., Yamazaki, K., Sawabe, T., Nakano, K., Kawasaki, K., Ezura, Y. \& Shinano, H. (1998). Bacillus horti sp. nov., a new Gramnegative alkaliphilic bacillus. Int J Syst Bacteriol 48, 565-571.

Yumoto, I., Yamaga, S., Sogabe, Y., Nodasaka, Y., Matsuyama, H., Nakajima, K. \& Suemori, A. (2003). Bacillus krulwichiae sp. nov., a halotolerant obligate alkaliphile that utilizes benzoate and $m$ hydroxybenzoate. Int J Syst Evol Microbiol 53, 1531-1536.

Yumoto, I., Hirota, K., Goto, T., Nodasaka, Y. \& Nakajima, K. (2005). Bacillus oshimensis sp. nov., a moderately halophilic, non-motile alkaliphile. Int J Syst Evol Microbiol 55, 907-911. 